\title{
Prevalence of colonic adenomas in patients with metabolic syndrome
}

\section{Występowanie gruczolaków jelita grubego u chorych z zespołem metabolicznym}

\author{
Dariusz Gajecki ${ }^{1}$, Radosław Kempiński², Elżbieta Poniewierka ${ }^{3}$ \\ 1Diagnostic Center, Strzegom, Poland \\ 2Department of Gastroenterology and Hepathology, Wroclaw Medical University, Poland \\ ${ }^{3}$ Dietetics Unit, Department of Gastroenterology and Hepathology, Wroclaw Medical University, Poland
}

Prz Gastroenterol 2012; 7 (3): 161-165 DOI: $10.5114 / p g .2012 .29883$

Key words: adenoma, metabolic syndrome, colonoscopy.

Słowa kluczowe: gruczolak, zespół metaboliczny, kolonoskopia.

Address for correspondence: Elżbieta Poniewierka MD, PhD, Dietetics Unit, Department of Gastroenterology and Hepathology, Wroclaw Medical University, 213 Borowska, 50-556 Wroclaw, Poland, e-mail: elzbieta.poniewierka@gmail.com

\begin{abstract}
Introduction: Seventy percent of colonic polyps are adenomas - benign neoplastic tissue deriving from epithelium with various grades of dysplasia. Metabolic syndrome is discussed as one of the risk factors for development of colonic adenomas. Aim: To evaluate the relation between metabolic syndrome and prevalence of colonic polyps.

Material and methods: In 2008-2011, 151 patients (aged 50-70 years) from the city of Strzegom were enrolled in a prophylactic programme. Each patient had the following examinations performed: physical examination, abdomen ultrasound, chest X-ray, oesophagogastroduodenoscopy, colonoscopy, ECG and laboratory tests. In females mammography and gynaecological examination were performed, and in males prostate-specific antigen (PSA) level was evaluated.

Results: The prevalence of adenomas was higher in patients with metabolic syndrome (33.3\% vs. $20.6 \%, p<0.05)$. Also higher prevalence of adenomas larger than $10 \mathrm{~mm}$ was found in patients with metabolic syndrome. HDL level above $95 \mathrm{mg} \%$ and HDL level $45-95 \mathrm{mg} \%$ with fulfilled criteria of metabolic syndrome were determined as risk factors of colonic adenoma development.

Conclusions: Metabolic syndrome can be a risk factor for development of colonic adenomas. Adenoma growth can be accelerated in metabolic syndrome. HDL molecules can promote colonic proliferation and formation of adenomas.
\end{abstract}

\section{Streszczenie}

Wstęp: Gruczolaki stanowią 70\% wszystkich polipów jelita grubego. Są nowotworami o charakterze tagodnym, ich komórki wywodzą się z nabłonka gruczołowego o różnym stopniu dysplazji i o różnej zdolności do transformacji złośliwej. Znane są dowody na zwiększoną częstość występowania gruczolaków u osób z zespołem metabolicznym.

Cel: Określenie związku pomiędzy występowaniem gruczolaków a zespołem metabolicznym.

Materiał i metody: Do programu profilaktycznego zakwalifikowano 151 osób pomiędzy 50. a 70. rokiem życia, zamieszkujących miasto i gminę Strzegom. Wykonano u nich następujące badania: endoskopię górnego i dolnego odcinka przewodu pokarmowego, badanie ultrasonograficzne jamy brzusznej, badanie elektrokardiograficzne (EKG), rentgenograficzne (RTG) klatki piersiowej, badania biochemiczne oraz w zależności od płci - badanie ginekologiczne, mammografię lub poziom PSA.

Wyniki: Wykazano istotnie statystycznie większą częstość występowania gruczolaków jelita grubego wśród osób z zespotem metabolicznym $(33,3 \%$ vs $20,6 \%, p<0,05)$. U tych pacjentów stwierdzano również istotnie wyższy odsetek większych gruczolaków, tj. $\geq 10 \mathrm{~mm}$ średnicy, w porównaniu z osobami bez zespołu metabolicznego. Wykazano ponadto, że wysokie stężenie cholesterolu HDL, tj. > 95 mg\%, lub stężenie cholesterolu HDL w granicach $45-95$ mg\% ze spełnionymi kryteriami rozpoznania zespołu metabolicznego wiąże się z występowaniem gruczolaków w jelicie grubym.

Wnioski: Zespół metaboliczny można uznać za czynnik ryzyka wystąpienia gruczolaków w jelicie grubym. Wzrost gruczolaków u pacjentów z zespołem metabolicznym może być przyspieszony. Cząsteczki HDL mogą odgrywać istotną rolę w procesach pobudzania nieprawidłowej proliferacji komórek jelita grubego prowadzącej do powstania gruczolaka. 


\section{Introduction}

Adenomas are benign neoplastic polyps, characterised by the presence of dysplasia. Dysplasia is epithelial cell overgrowth with change of tissue architecture and formation of tubular, villous or tubulovillous structure. The diagnosis is based histologically on the structure of polyps. Serrated adenoma is a specific type of adenoma with architecture of hyperplastic polyps and dysplastic characteristics of adenoma [1].

Known risk factors for development of adenomas include age above 60, male sex, and genetic background. The risk of malignancy was described in all adenomas, depending on their size: $1 \%$ of malignancy is seen in polyps $5-10 \mathrm{~mm}$ of size and several percent in polyps larger than $10 \mathrm{~mm}$ [2].

Visceral obesity is considered one of the risk factors for colon cancer formation. Probably hyperinsulinism and insulin resistance are responsible for carcinogenesis in obesity. Recently many reports concerning the role of obesity, insulin resistance and metabolic syndrome in colonic polyps development have been published [3, 4].

\section{Aim}

The aim of the study was to evaluate the relation between metabolic syndrome and prevalence and size of colonic polyps in asymptomatic patients between 50 and 70 years of age.

\section{Material and methods}

In 2008-2011, 151 asymptomatic patients (aged 50-70 years) from the city of Strzegom were enrolled in a prophylactic health programme. Ten patients ful- filled pre-study exclusion criteria (history of gastrointestinal bleeding) and they were advised on routine diagnostic procedures. Each enrolled patient had the following examinations performed: physical examination, abdominal ultrasound, chest X-ray, oesophagogastroduodenoscopy, colonoscopy, ECG, and laboratory tests. In females mammography and gynaecological examination were performed, and in male patients PSA level was evaluated. Examinations were performed in Strzegom Diagnostic Center. Histological evaluation was performed in NZOZ "HISTIOTEST" in Wałbrzych or NZOZ "ANMED" in Wrocław. Metabolic syndrome was diagnosed using International Diabetes Federation criteria: visceral obesity defined as waist diameter $\geq 80 \mathrm{~cm}$ in females and $\geq 94 \mathrm{~cm}$ in males and 2 of the following:

- serum triglyceride level above $150 \mathrm{mg} / \mathrm{dl}$ or patient is on equivalent therapy,

- serum HDL level lower than $40 \mathrm{mg} / \mathrm{dl}$ in men and $50 \mathrm{mg} / \mathrm{dl}$ in women or patient is on equivalent therapy, - systolic blood pressure above $\geq 130 \mathrm{~mm} \mathrm{Hg}$ or diastolic above $\geq 85 \mathrm{~mm} \mathrm{Hg}$ or patient is on equivalent hypertensive therapy,

- fasting glucose $\geq 100 \mathrm{mg} / \mathrm{dl}$ or diagnosed diabetes type 2.

Statistical analysis was performed in the Statistica 9.0 programme.

\section{Results}

The studied group consisted of 151 patients, mean age 59 (50-70 years), 88 women and 63 men. According to the criteria of metabolic syndrome all patients were divided into two groups: with or without metabolic syndrome. In Table I demographic, clinical and biochemical

Table I. Demographic data, selected clinical and laboratory findings in patients with and without metabolic syndrome

Tabela I. Dane demograficzne, wybrane dane kliniczne i laboratoryjne u pacjentów z zespołem metabolicznym i bez niego

\begin{tabular}{lccc} 
Parameter & Without metabolic syndrome $(n=97)$ & With metabolic syndrome $(n=54)$ & Value of $p$ \\
\hline Male $[\%]$ & 39.2 & 46.3 & NS \\
\hline Age $[$ years] & $59.1 \pm 4.7$ & $58.9 \pm 4.6$ & NS \\
\hline Weight $[\mathrm{kg}]$ & $75.7 \pm 12.2$ & $84.2 \pm 13.7$ & $166.3 \pm 9.3$ \\
\hline Height $[\mathrm{cm}]$ & $166.5 \pm 10.0$ & $30.4 \pm 4.2$ & $\mathrm{NS}$ \\
\hline BMI $\left[\mathrm{kg} / \mathrm{m}^{2}\right]$ & $27.3 \pm 4.0$ & $100.7 \pm 10.9$ & $\mathrm{NS}$ \\
\hline Waist $[\mathrm{cm}]$ & $93.4 \pm 9.6$ & $139.5 \pm 16.2$ & $\mathrm{NS}$ \\
\hline Systolic BP $[\mathrm{mm} \mathrm{Hg}]$ & $127.3 \pm 13.7$ & $85.4 \pm 7.9$ & $<01$ \\
\hline Diastolic BP $[\mathrm{mm} \mathrm{Hg}]$ & $79.5 \pm 9.1$ & $54.3 \pm 16.0$ & $<001$ \\
\hline HDL $[\mathrm{mg} \%]$ & $65.1 \pm 17.3$ & $157.2 \pm 56.3$ & $108.9 \pm 13.5$
\end{tabular}


data in patients with or without metabolic syndrome are shown.

Metabolic syndrome was diagnosed in 54 patients (35.8\%). Adenomas were found in 38 patients (25.2\%), 18 patients (33.3\%) with metabolic syndrome and 20 patients (20.6\%) without metabolic syndrome. Prevalence of adenomas was significantly higher in patients with metabolic syndrome $(p<0.05)$ (Figure 1). In 20 patients adenomas were larger than $10 \mathrm{~mm}$ in size.

In Table II the prevalence of adenomas larger and smaller than $10 \mathrm{~mm}$ is shown in patients with or without metabolic syndrome. The prevalence of adenomas larger than $10 \mathrm{~mm}$ was significantly higher in patients with metabolic syndrome $(p<0.05)$ (Table II). Table III shows demographic data, clinical features and laboratory findings of patients with respect to adenoma size. Patients with adenoma larger than $10 \mathrm{~mm}$ were significantly older and had higher body weight (Table III). Colon cancer was found in 2 patients (1.3\%). Table IV shows the histological analysis of polyps.

Using regressive classification tree analysis we tried to identify compounds of metabolic syndrome connected with adenoma development. Adenoma development was connected with $\mathrm{HDL} \geq 95 \mathrm{mg} \%$ or $\mathrm{HDL}$ level between $45 \mathrm{mg} \%$ and $95 \mathrm{mg} \%$ with fulfilled criteria of metabolic syndrome (Figure 2).

\section{Discussion}

Endoscopic polypectomy of colonic adenomas is the most effective prevention of colorectal cancer development [5]. In Poland screening colonoscopy is recommended starting from age 50 years and repeated every 10 years [6]. In patients with family history of colorectal cancer colonoscopy should be started earlier and repeated more frequently [7]. Identification of

Table II. Adenoma size in patients with and without metabolic syndrome

Tabela II. Wielkość gruczolaków u chorych z zespołem metabolicznym i bez niego

\begin{tabular}{lcc} 
Adenoma & $\begin{array}{c}\text { With metabolic } \\
\text { syndrome }(n=18)\end{array}$ & $\begin{array}{c}\text { Without metabolic } \\
\text { syndrome }(n=20)\end{array}$ \\
\hline$<10 \mathrm{~mm}, n[\%]$ & 5 & 13 \\
\hline$\geq 10 \mathrm{~mm}, n[\%]$ & 13 & 7
\end{tabular}

Table IV. Histology of adenomas

Tabela IV. Histologia gruczolaków

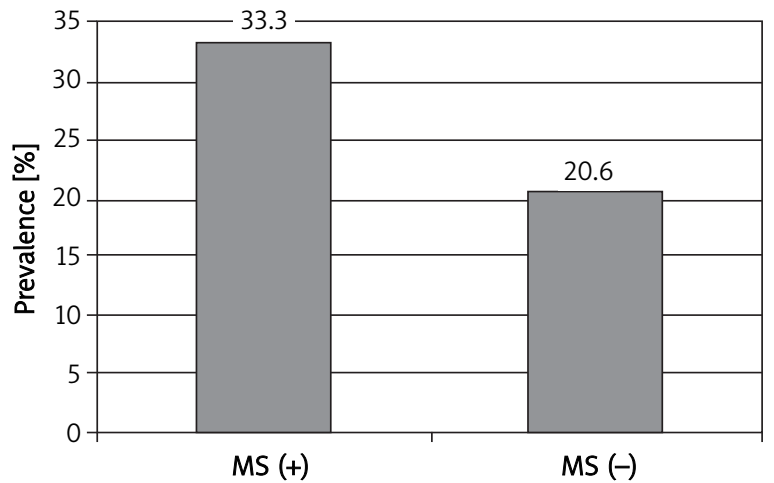

Fig. 1. Prevalence of colonic adenomas in patients with and without metabolic syndrome (MS)

Ryc. 1. Częstość występowania gruczolaków jelita grubego u chorych z zespotem metabolicznym i bez niego

risk factors is important for proper screening design. Apart from age and family background other factors may play a role in colorectal cancer development [8]. Recent data show that cancer can grow even in small adenomas [9].

Table III. Demographic data, selected clinical and laboratory findings in patients with adeno$\mathrm{ma}<10 \mathrm{~mm}$ and adenoma $\geq 10 \mathrm{~mm}$

Tabela III. Dane demograficzne, wybrane dane kliniczne i laboratoryjne u pacjentów z gruczolakami o średnicy mniejszej i większej niż $10 \mathrm{~mm}$

\begin{tabular}{lccl} 
Parameter & $\begin{array}{c}\text { Adenoma } \\
<10 \mathrm{~mm}\end{array}$ & $\begin{array}{c}\text { Adenoma } \\
\geq 10 \mathrm{~mm}\end{array}$ & Value of $p$ \\
\hline Male [\%] & 55.6 & 40.0 & NS \\
\hline Age [years] & $58.0 \pm 5.1$ & $61 \pm 4.0$ & $<0.05$ \\
\hline Weight [kg] & $78.4 \pm 13.8$ & $80.7 \pm 15.5$ & NS \\
\hline Height [cm] & $167.8 \pm 6.4$ & $161.7 \pm 15.6$ & NS \\
\hline BMI [kg/m²] & $27.7 \pm 4.0$ & $31.1 \pm 5.7$ & $<0.05$ \\
\hline Waist [cm] & $96.9 \pm 11.2$ & $100.4 \pm 11.0$ & NS \\
\hline Systolic BP [mm Hg] & $130 \pm 11.9$ & $137.8 \pm 20.8$ & NS \\
\hline Diastolic BP [mm Hg] & $79.8 \pm 9.6$ & $83.2 \pm 9.9$ & NS \\
\hline HDL [mg\%] & $68.9 \pm 25.0$ & $60.0 \pm 17.3$ & NS \\
\hline TG [mg\%] & $118.6 \pm 43.4$ & $135.1 \pm 51.3$ & NS \\
\hline Glucose [mg\%] & $101.8 \pm 11.5$ & $104.1 \pm 15.8$ & NS
\end{tabular}

\begin{tabular}{lcccc} 
& \multicolumn{4}{c}{ Adenoma histology } \\
\cline { 2 - 5 } & Tubular & Tubulo-villous & Villous & Serrated \\
\hline Without metabolic syndrome & 17 & 2 & 0 & 1 \\
\hline With metabolic syndrome & 13 & 1 & 0 & 2
\end{tabular}




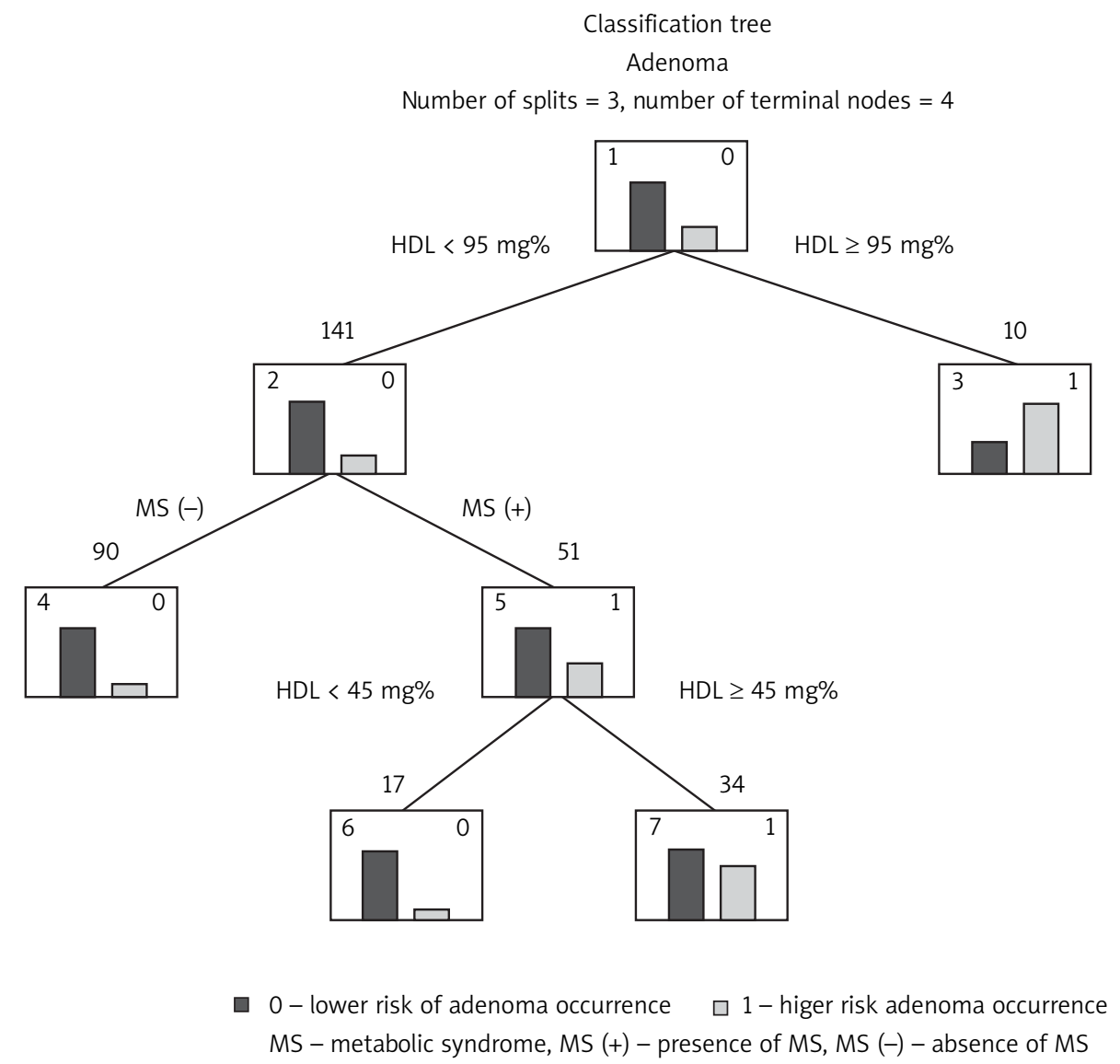

Fig. 2. The results of CART analysis

Ryc. 2. Wynik analizy CART

Patients with metabolic syndrome had significantly higher body weight and higher body mass index (BMI) and waist diameter, but the difference was not statistically significant compared to patients without metabolic syndrome, probably due to the small sample size.

In our study group adenomas were found in $25 \%$ of patients, colon cancer in 2 patients (1.3\%). Similar prevalence of adenomas was reported by other authors in higher risk populations [10], while in the general population adenomas were found less frequently. Other studies found in the general population slightly lower or even higher prevalence of adenomas than in our study [11]. The high prevalence of adenomas in our group can be explained by the relatively high age of the studied group. In addition, in our prophylactic programme we observed higher admittance of patients with familial cancer history.

The results of our study proved higher prevalence of colonic adenomas in patients with metabolic syndrome. It was also reported by other authors [12-14]. There is an especially strong correlation between visceral obesity and colonic adenomas [13].

Insulin resistance and hyperinsulinemia in metabolic syndrome are discussed as factors that play a role in adenoma development as they increase the level of insulin-dependant growth factors. Hyperinsulinaemia leads to increase of insulin-like growth factor-1 (IGF-1), higher leptin level and lower adiponectin. All these factors can promote carcinogenesis. Colonic epithelium exchange is increased and apoptosis inhibited [15], though all mechanisms are not known.

In our study we found $53 \%$ of adenomas larger than $10 \mathrm{~mm}$, similar to data reported by other authors (Hodadoostan et al. - 41\% [16]). We also found that prevalence of adenomas larger than $10 \mathrm{~mm}$ was higher in patients with metabolic syndrome, which may be explained by faster adenoma growth in metabolic syndrome.

No reports are available concerning the role of increased HDL level in the development of colonic adenomas. HDL level is one of the metabolic syndrome cri- 
teria but data about its role in adenoma development are ambiguous. Some authors did not find an association but others confirmed that decreased HDL is connected with increased risk of adenoma development $[12,17]$. Our results might be explained by a new statistical analysis method: regressive classification tree analysis. So far in study designs only subgroups with normal or decreased HDL have been analysed [10]. It was shown just recently that large HDL molecules also known as dysfunctional HDL are no longer cardioprotective and can be a risk factor of cardiovascular diseases [18, 19]. Yang et al. reported increased prevalence of cardiovascular disease in patients with colonic adenomas and colorectal cancer, which can be explained by the same pathway [20]. The results of our study are based on HDL cut-off values connected with increased risk of adenoma (learning study) and need confirmation in a prospective study (validation study). Concerning the specification of statistical analysis lower prevalence of adenomas in validation study is expected in patients with an HDL level below $95 \mathrm{mg} \%$.

In our study we also found higher prevalence of colonic adenomas in patients with metabolic syndrome and an HDL level between 45 mg\% and 95 mg\%. Hypertriglyceridaemia, insulin resistance and hyperinsulinism decrease the HDL level. The results of the study proved that lack of this inhibition might be connected with increased risk of adenoma, while in patients with a low HDL level and metabolic syndrome the prevalence of adenomas is low. Our study does not fully explain the nature of this phenomenon but indicates the possible complex associations between components of metabolic syndrome, especially HDL and prevalence of metabolic syndrome.

The main limitation of the study was the low number of patients enrolled and lack of a validation group to confirm the $95 \mathrm{mg} \%$ HDL cut-off value.

\section{Conclusions}

Metabolic syndrome can be a risk factor for development of colonic adenomas. Adenoma growth can be accelerated in metabolic syndrome. HDL molecules can promote colonic proliferation and formation of adenoma.

\section{References}

1. Orłowska J, Kiedrowski M. Serrated adenomas, hyperplastic polyposis and carcinoma of the colorectum. Post Nauk Med 2009; 22: 111-7.

2. Butterly LF, Chase MP, Pohl H, et al. Prevalence of clinically important histology in small adenomas. Clin Gastroenterol Hepatol 2006; 4: 343-8.

3. Kim MC, Kim CS, Chung TH, et al. Metabolic syndrome, lifestyle risk factors, and distal colon adenoma: a retrospective cohort study. World J Gastroenterol 2011; 17: 4031-7.
4. Bassett JK, Severi G, English DR, et al. Body size, weight change, and risk of colon cancer. Cancer Epidemiol Biomarkers Prev 2010; 19: 2978-86.

5. Smith RA, Cokkinides V, Brooks D, et al. Cancer screening in the United States, 2010: a review of current American Cancer Society guidelines and issues in cancer screening. CA Cancer J Clin 2010; 60: 99-119.

6. Regula J, Zagorowicz E, Butruk E. Implementation of a national colorectal cancer screening program. Curr Colorectal Cancer Rep 2006; 2: 25-9.

7. Jasperson KW, Tuohy TM, Neklason DW, et al., Hereditary and familial colon cancer. Gastroenterology 2010; 138: 2044-58.

8. Hoffmeister M, Schmitz S, Karmrodt E, et al. Male sex and smoking have a larger impact on the prevalence of colorectal neoplasia than family history of colorectal cancer. Clin Gastroenterol Hepatol 2010; 8: 870-6.

9. Hisabe T, Tsuda S, Matsui T, et al.Natural history of small colorectal protuberant adenomas. Dig Endosc 2010; 22 Suppl 1: S43-6.

10. Fatemi SR, Shivarani S, Malek FN, et al. Colonoscopy screening results in at risk Iranian population. Asian Pac J Cancer Prev 2010; 11: 1801-4.

11. Heitman SJ, Ronksley PE, Hilsden RJ, et al. Prevalence of adenomas and colorectal cancer in average risk individuals: a systematic review and meta-analysis. Clin Gastroenterol Hepatol 2009; 7: 1272-8.

12. Liu CS, Hsu HS, Li Cl, et al. Central obesity and atherogenic dyslipidemia in metabolic syndrome are associated with increased risk for colorectal adenoma in a Chinese population. BMC Gastroenterol 2010; 10: 51.

13. Kang HW, Kim D, Kim HJ, et al. Visceral obesity and insulin resistance as risk factors for colorectal adenoma: a cross-sectional, case-control study. Am J Gastroenterol 2010; 105: 178-87.

14. Morita T, Tabata S, Mineshita M, et al. The metabolic syndrome is associated with increased risk of colorectal adenoma development: the Self-Defense Forces health study. Asian Pac J Cancer Prev 2005; 6: 485-9.

15. Chiu-Shong L, Hua-Shui H, Chia-Ing J, et al. Central obesity and atherogenic dyslipidemia in metabolic syndrome are associated with increased risk for colorectal adenoma in a Chinese population. BMC Gastroenterology 2010; 10: 51.

16. Hodadoostan MK, Reza F, Elham M, et al. Clinical and pathology characteristics of colorectal polyps in Iranian population. Asian Pac J Cancer Prev 2010; 11: 557-60.

17. Sato T, Takeda H, Sasaki Y, et al. Increased homeostasis model assessment-insulin resistance is a risk factor for colorectal adenoma in Japanese males. Tohoku J Exp Med 2011; 223: 297-303.

18. Ragbir S, Farmer JA. Dysfunctional high-density lipoprotein and atherosclerosis. Curr Atheroscler Rep 2010; 12: 343-8.

19. Dullaart RP. Increased coronary heart disease risk determined by high high-density lipoprotein cholesterol and C-reactive protein: modulation by variation in the CETP gene. Arterioscler Thromb Vasc Biol 2010; 30: 1502-3.

20. Yang SY, Kim YS, Chung SJ, et al. Association between colorectal adenoma and coronary atherosclerosis detected by CT coronary angiography in Korean men; a cross-sectional study. J Gastroenterol Hepatol 2010; 25: 1795-9. 